\title{
Modeling the Protagonist: The Strategic Use of Discourse Voices
}

\author{
Paul Van den Hoven
}

Published online: 29 August 2010

(C) The Author(s) 2010. This article is published with open access at Springerlink.com

\begin{abstract}
An argumentative text can be reconstructed as an argumentative discussion between a protagonist and an antagonist. However, such a text is usually not a literal report of a discussion. It is the author of the text who determines how issues are presented, how claims are modeled, how the development of the discussion is presented. Especially when a text has embedded discourse voices that can fulfill the roles of protagonist or antagonist, the author of the text can strongly suggest a specific assignment, suppressing alternatives. In this article examples are presented that show how an author exploits linguistic means-a strategic choice of causal connectives-to suggest a specific reconstruction. The question is raised whether a derailment of this behavior of the author should be characterized as committing the fallacy of the straw man.
\end{abstract}

Keywords Dialectical discussion - Protagonist - Causality - Subjectivity · Rhetorical strategy

\section{Introduction}

According to the pragma-dialectic theory an argumentative text can be reconstructed as a dialectical discussion between a protagonist and an antagonist (Van Eemeren and Grootendorst 1984). This means-among other things-that one of the discourse voices has to be assigned the role of protagonist towards a standpoint. In the reconstruction it must be determined what the exact standpoint is that this discourse voice as a protagonist defends against the doubt of an antagonist and what the common grounds are that the protagonist and antagonist share. However, an argumentative text is not a literal report of a discussion. It is the author of the text

\footnotetext{
P. Van den Hoven $(\square)$

Utrecht University, Utrecht, Netherlands

e-mail: p.vandenhoven@uu.nl
} 
who determines how issues are presented, how standpoints are modeled, how the development of the discussion is presented. The author of the text can strongly suggest a specific reconstruction, even when he himself takes up the role of the protagonist. This article focuses on more complex situations. The focus is on situations where the author of a text does not take up the role of protagonist himself, but suggests the role of the protagonist be assigned to an embedded discourse voice. Such a situation may sound rather complicated, but it turns out to occur quite frequently.

If an author does not take up the role of protagonist himself but assigns this role-with the argumentative obligations that are attached to it- to an embedded voice, he has latitude to present the protagonist's position. In this study the question is explored how authors use this latitude. Do we find indications that the protagonist's position is presented in such a way that it suggests a rational reconstruction that favors the author's own interests concerning the issue that is discussed? If so, how should we evaluate such behavior of the author? Should it be evaluated as committing a fallacy, even when the author seems to sincerely report the protagonist's speech acts?

These questions are investigated by studying one specific linguistic means that the author of the text may exploit. A protagonist can present his standpoint as a subjective, epistemic position, based on a certain 'force' that brought him to this position. A protagonist can also present his standpoint as an 'objective' position, namely as the consequence of a causal relation in the 'real', socio-physical world. In the Dutch language this difference can be expressed by using want as a connective in the first situation, omdat as a connective in the second situation. In a polyphonic text therefore the author of the text can model a protagonist using want, or a protagonist using omdat. In a corpus the polyphonic situations are studied to find out how the author fills in this latitude.

\section{Theoretical Framework}

Talmy (1988) analyses 'causality' in a very broad sense as any force dynamic relation. His analysis of causality includes causal relations in the 'real' world as well as subjective reasons that motivate a person to adopt a standpoint. Talmy's analysis is influential in cognitive text linguistics (Sweetser 1990, Verhagen 2005). On the basis of the analysis of (text) linguistic phenomena Sweetser (1990) - in a widespread but not always clear terminology-distinguishes the socio-physical domain from the epistemic domain. In her study she investigates the relations between this mental domain of the (claimed) 'real' physical and social phenomena and this mental domain of the knowing (epistemic) subject. She finds many (text) linguistic relations.

From the theoretical framework of an argument theory these findings are not surprising. An (assumed) causality $A$ causes $B$ in the socio-physical world may be a subjective (epistemic) reason to adopt standpoint B when A seems to be at hand. In a reconstruction of a discussion ( $\mathrm{I}$ use the concepts of the pragma-dialectic argumentation theory as explained in Van Eemeren and Grootendorst 1984) we 
distinguish a confrontation stage in which an actor brings forward a point of view that may meet doubt. In this stage the actor can add a motivation why he holds his point of view. Together these two speech acts-bringing forward the point of view and adding a motivation-form a force dynamic, 'causal' relation. The motivation is the force that makes the actor hold this point of view. Such a relation is as yet situated in the epistemic domain of this actor.

A relation between a standpoint and an argument may depend on a (claimed) relation between a cause and an effect in the socio-physical world (namely in case of an argumentation based on causality), but these two relations should not be identified. In the confrontation stage the actor informs his audience about a personal point of view that he holds (epistemic), and he justifies this speech act. The actor has not been challenged yet to defend this point of view. It still has to be determined whether there will be an argumentative discussion and what exactly will be the stake of that discussion.

Next in the rational reconstruction a second actor comes on stage and challenges the tenability of this point of view as a reasonable point of view. At least three things can happen.

(1) The first actor admits that his point of view is purely personal, not to be recognized and certainly not to be shared by the other. No discussion will follow, we stay within this personal epistemic domain, no social consequences of whatever kind are claimed by the initial actor.

(2) More often the initial actor will at least claim that the other should recognize that he can hold this point of view as a reasonable person. Within the epistemic domain he can reformulate his point of view as: It is reasonable that I hold this point of view, and again the initial actor can add a motive. But, as reasonableness is a social concept, if the other challenges the tenability of this point of view, a discussion should start. The initial actor should take the role of protagonist, the other the role of antagonist. We enter the argumentation stage. Now the protagonist is obliged to bring forward an argumentation in which he states that there is some force that makes it reasonable for a person in his situation to hold this point of view. This causal relation cannot be an element in his personal epistemic domain. To meet the pragma-dialectic commitment of socialization, this causal relation should 'exist' independent of the speaker in the socio-physical domain that he shares with the antagonist. However, because in the force there may be references to specifics of the protagonists situation that differ from the situation the antagonist is in, the protagonist has no claim that the other should share his point of view.

(3) The third option may be even more common. The initial actor claims that the other should share his point of view. Within the epistemic domain he can reformulate his point of view as: All reasonable people [within the relevant community] should hold this point of view. The initial actor can add a motive, resulting in a causal relation that is situated in the epistemic domain. But because the tenability of his point of view will be doubted or even contradicted, the initial actor as the protagonist in the argumentation stage should bring forward an argument that entails a causal relation in the 
socio-physical domain. This should be any causal relation that presents a force that causes it to be reasonable for every participant to hold the point of view. Depending on the rules agreed upon in the opening stage, several causal relations can be brought up as an element in a (complex) argumentation. For example, a force can be claimed that causes the point of view to be a physical 'fact': "One should hold this point of view because of this specific physical regularity". Or maybe an accepted authority within the relevant community can be brought up to establish a social 'fact': "One should hold this point of view because the Supreme Court decided so". These causal relations are claimed to 'exist' within the shared socio-physical domain, independent of the protagonist.

Now we can combine the text linguistic and the pragma-dialectical frameworks. Because an argumentative text is usually not a direct transcript of an actual discussion, the author of the text can (re)present a protagonist's position in many ways. Out of the many relevant causal (force dynamic) relations that are part of the rational reconstruction of the discussion in the confrontation stage or the argumentation stage, the author can choose one to (re)present a protagonist's position in an argumentative text. This can be a relation out of the pragmaepistemic domain, but also a relation out of the socio-physical domain; it can be a relation with the far reaching claims of option (3) or the more modest claims of option (2).

Languages have rich registers to present causal relations as an element of a (subjective) epistemic domain or as a (claimed) element of a socio-physical domain. This we can use to explore the question whether the author of a polyphonic argumentative text presents the protagonist's position in such a way that it suggests a rational reconstruction that favors the author's own interests concerning the issue. In Dutch the backward causal connective want seems to be specific for the epistemic domain, omdat for the socio-physical domain (for a foundation of this claim, see Van den Hoven 2006; in Houtlosser 1995 we find a similar claim, but he uses the argument theoretical framework; Pit 2006 and Stukker 2005 are compatible with this view). Therefore the research question can be stated as: does the author of a polyphonic argumentative text use the causal connectives want and omdat to present the protagonist's position in such a way that it suggests a rational reconstruction that favors the author's own interests concerning the issue that is discussed?

\section{The Corpus}

From a digital source of Dutch newspapers 50 cases of want ... immers and 50 cases of omdat ... immers have been selected automatically, extending the time period until the number of 50 had been reached. The Dutch immers means after all, claiming that what follows is something that the hearer has admitted or should admit as incontestable. Together with the causal connective (a maximum of three words was allowed between the causal connective and immers) this guarantees that the text fragments present clearly argumentative relations. 
The examples differ in the connective that explicitly indicates the causal relation. Either the Dutch want is used, or the Dutch omdat. In principle, these connectives are interchangeable, although the word order in want-clauses is slightly different from the word order in omdat-clauses because want is a coordinating conjunction, omdat a subordinate conjunction. However, want situates the causal relation within a personal epistemic domain, omdat in the shared socio-physical domain. This distinction we use as a point of departure in our analysis.

In a first analysis the cases were determined in which the author of the text does not take up the role of protagonist himself. Although this study is based on corpus research, the method has not been to count a limited number of surface characteristics. Even this first analysis frequently requires extensive interpretation. Therefore all analyses have been done by two analysts. Charles Forceville writes on April 28, 2001, translated: "The postmodern objection that this is true for every character, [omdat] characters [immers] are no humans, does not impress me". This fragment has of course been classified as polyphonic; Forceville himself is not the protagonist of "This is true for every character", and he clearly opposes the protagonist that he 'found' or constructed. This is an example of a clear case for the analysts. The following fragment however by Margriet van der Heijden from July 7, 2001 seems very similar and may seem a clear example of polyphony too: "On the other hand the expectation that the number of concertgoers would increase [omdat immers] the level of education of the Dutch increased proved to be wrong". But it is not. After a careful reading of the context, it becomes clear that the author presents herself as one of those people who expected this increase, therefore fulfills the role of protagonist herself and admits that she has to withdraw her standpoint. This frequent need for extensive interpretation seems to be inherent in this research and is a point to be taken up in the discussion.

From the 50 want ... immers cases about $60 \%$ is polyphonic and in about $2 / 3$ of these cases the author seems to disagree with the protagonist that he presents. In the omdat ... immers cases about $50 \%$ is polyphonic. In about $1 / 3$ of the polyphonic cases the author disagrees with the protagonist that he presents. These figures do not reveal anything yet about the question whether the author behaves strategically. Each of the four options can represent a credible, correct report of what actually the discourse voice said or meant in a certain stage of the interaction, or can be a 'tailored' version that strongly favors the author's interests. We claim on the basis of a qualitative analysis that such 'strategic' behavior of the author is demonstrable in at least $15 \%$ of the examples in the corpus and may be at hand in much more. In the next section we will illustrate this claim with examples from the corpus. With example 1 we illustrate the difficulties in determining a 'strategic' behavior, reason why we claim that $15 \%$ is an underestimation. The examples $2-6$ are representative for the $15 \%$ clear cases.

\section{Corpus Examples}

Example 1 represents a frequent type in the omdat-corpus. Omdat is put in the mouth of a specialist who argues (or maybe better: explains) a not so controversial 
as well as unknown point of view. In the following fragment the author quotes approvingly the words of an acknowledged expert:

\section{Example 1}

Medicijnen tegen virussen zijn moeilijk te maken omdat virussen immers alleen binnen een cel actief zijn.

[Medicines against viruses are hard to make] omdat immers [viruses are only active within a cell].

By using omdat the author presents the words of an expert who informs us about a 'fact' we are supposed to acknowledge; the medical expert explains why medicines against viruses are hard to make. He presents this as factual in the socio-physical domain. A default mechanism is that when the author does not explicitly contest this point of view, he implicitly endorses it, thereby assimilating it from the (shared) socio-physical domain to the author's personal-epistemic domain (Spooren and Jaspers 1990). Reasonable opponents either acknowledge claimed elements of the socio-physical domain or clearly contest them. That explains why a causal relation presented with omdat is either acceptable for the author, or is obviously absurd from the context, or will be explicitly contested or even ridiculed.

We quote this fragment because it illustrates perfectly that when the author uses omdat ... immers and endorses the defended standpoint himself, analysts can seldom determine whether the author acts strategically or not. Did the expert himself use omdat ... immers in his original words? Is the issue indeed rather uncontroversial? Or did the expert formulate his position more carefully as a subjective position, placing the causal relation in the pragma-epistemic domain, because he is aware of the fact that his opinion about the difficulty of the making of these medicines is indeed controversial? In that case it is the author of the text who transfers the causal relation from the pragma-epistemic domain to the socio-physical domain. In this case such a strategic transfer by the author seems implausible. But, that it seems to be implausible is an interpretative judgment of the analysts. Cases such as example 1 make us state that strategic behavior of the author is demonstrable in at least 15 of the examples in the corpus but may be at hand in much more. In the remaining five examples such behavior seems obviouslyalthough never with a $100 \%$ certainty — at hand.

The second fragment illustrates 'prototypically' the phenomenon we deal with. Here the author strongly disagrees with the discourse voice that he presents as the protagonist. It seems no coincidence that he puts the use of omdat ... immers in the mouth of the protagonist(s), resulting in an evidently invalid argumentation, while want ... immers would at least have been less ridiculous.

The work of some researchers from Limburg province ("Limburgers") was selected as an example of foolish research. The scholars make the mistake of publishing a reaction. This gives a rhetorically skilled columnist a chance to hit again. The columnist presents them as the protagonist of a standpoint, using omdat ... immers. 


\section{Example 2}

De Limburgers reageerden als door een wesp gestoken, en schreven in een ingezonden brief dat hun artikel heus wel goed was-omdat het immers gepubliceerd was.

[The 'Limburgers' responded as if they were stung by a wasp and wrote in a send in letter that their article really was good] omdat immers [it had been published].

Here omdat marks the causal relation as an element in the socio-physical domain. The causality as presented here strongly suggests that the Limburgers intend to defend that the fact that the article was published is a force that makes the research good. The word order as well as the use of immers suggests that these are their literal words. But are they? We do not know.

The intended epistemic position of the 'Limburgers' is not clear. When we reconstruct the maximal argumentative interpretation, the epistemic causal relation is: That the article has been published 'causes' that all reasonable people [within the relevant community] should hold the point of view that the article is good. To defend the epistemic position it is not entirely nonsensical. Why? Because the underlying socio-physical causality can be that of a sign (also called abductive) relation: That the article has been published is a sign that the article is good. This sign relation is based on the 'real' (socio-physical) causal relation: That the article is good [in the eyes of the editors] 'causes' that it has been published. In the end, this is the causal mechanism that we scholars all want our deans to accept (at least for a sample of refereed quality journals).

The author does not represent this part of the discussion by any epistemic causal relation (using want). He could have used for example:

Ze schreven dat hun artikel kennelijk heus wel goed was-want het was immers gepubliceerd.

[They wrote that their article apparently was good] want immers [it had been published].

Now kennelijk (apparently) and want indicate that they do not claim that publication makes the article good, but they obviously claim that publication makes them hold the opinion that the article was good.

The author also does not present the sign relation as an element of the sociophysical domain (You/reasonable people should hold the point of view that the article is good [omdat] it has been published). Nor chooses the author to present the underlying causality as an element of the socio-physical domain (That the article is good [in the eyes of the editors] 'causes' that it has been published). For example:

Ze schreven dat hun artikel (heel waarschijnlijk) was gepubliceerd omdat het goed was.

[They wrote that their article (most likely) had been published] omdat [it was good].

All these (and several others) causal relations could have been chosen to (re)present this part of the discussion. But no, the author and ironic columnist puts a factual 
claim in the mouth of the embedded voice, based on a socio-physical causal relation (using omdat) that strongly suggests the that Limburgers want to defend that the fact that the article was published is a force that makes the research good.

In the corpus there are three clear cases in which the author lays omdat ... immers in the mouth of an embedded voice, and immediately afterwards explicitly ridicules the argumentation of that voice. There are several others were the author is lightly ironic or scornful.

In the corpus we find a complementary set of want-cases. These are polyphonic cases in which the author does not overtly and directly formulate his disagreement, but nevertheless intends to make sure that the causality does not transmit to his personal epistemic domain (and to that of his readers). He constructs this by putting want in the mouth of the embedded voice, which situates the causal relation within the personal epistemic domain of the embedded voice; now such transmission is not default. Many polyphonic want-cases in the corpus can be explained this way. In example 3 the author reports the writings of a Schutzstaffel-periodical, a publication of the Nazi regime:

\section{Example 3}

Er was maar weinig verschil tussen de 'Wallstreetkapitalist' en de 'bolsjewistische Untermensch', want achter beiden school immers de 'eeuwig joodse wereldparasiet'.

There was hardly any difference between the 'Wall street capitalist' and the 'bolshevik Untermensch'] want immers [behind both hides the 'eternal Jewish world parasite'].

The formulation suggests that these were the literal words of the periodical. But this periodical was in German, so it is the author's choice to use want in the translation. He wants to dissociate himself from this causal relation. Had he used omdat, of course this context would have been strong enough for any reader to assume that the author does not acknowledge the socio-physical causality that would have been claimed then. Nevertheless want is explained by the writer's sentiments. He does not want the reader to do the work, he himself wants to mark a clear dissociating position. There are several ways to do this. He does not choose to contest the voice explicitly, he does not choose to put the entire sequence between quotation marks (maybe because it is not a literal quotation), but he marks the relation in the personal pragma-epistemic domain using want, thereby emphasizing the voice of the SSperiodical.

Is this explanation not a much too elaborate for such a minor choice (want versus omdat) in a text? There are many reasons not to think so. The most important one seems to me that (1) languages have very elaborate means to mark causal relations (in Dutch it is easy to sum up twenty or more connectives, and besides connectives there are numerous other means), (2) most causal relations are not indicated by any connective so when a connective is used this seems to be significant.

A related example of the suggestive figure we just saw we find in example 4. There has been a horrible New Years Eve fire in a Dutch pub, due to all kinds of 
non-fireproof ornaments. The article is about the trial against the owner, Jan Veerman. It says (translated):

\section{Example 4}

Only if Jan Veerman would have done everything to prevent that a life threatening situation would occur [...] it would have been impossible for him to foresee it. But no, Jan left the supervision to the assertiveness of the personnel. He knew that is was going to be crowded, because [want] after all that was how it went every year, nevertheless he did not take special measures. [...] All time low was according to the public prosecutor that the personnel distributed sparklers.

Because want places the causality in an epistemic domain, it requires a voice related to that domain. Here there are two candidates, the public prosecutor and Jan Veerman. The use of want indicates that That was how it went every year can be read as the force that brought the public prosecutor to his interpretation of Veerman's thoughts (the causal relation is in the personal epistemic domain of the prosecutor). But it is also suggested that the causal relation is situated in the personal epistemic domain of Veerman: I, Jan Veerman knew that is was going to be crowded, because/since after all that was how it went every year. This almost creates the impression that the suspect is confessing.

The corpus contains four other clear examples of this rhetorical use of want. These are all examples in which the use of want suggests that in the complex polyphony (in example 4 we have the author, the prosecutor, and Veerman), a voice that 'formally' does not speak, nevertheless sounds. One of them is this 'secretly overhear confession' of the former French president:

\section{Example 5}

De Franse president vindt het gemakkelijker een ronkende verklaring te ondertekenen [...] dan de maatregelen te nemen die nodig zijn. Want dan krijgt hij immers de machtige Franse vakbonden over zich heen.

[The French president thinks it easier to sign a roaring declaration [...] then to take the necessary measures] want immers [he gets the opposition of the mighty French labour unions].

Here indeed a plausible reading is that the force is the force that brought the author to his epistemic position that these are the thoughts of the French president. But a second reading is that in which the last part is - as quasi direct speech-put in the mouth of the French president. The use of want emphasizes this second reading.

A limited number of examples can never present a strong proof. But so far all choices between omdat ... immers and want ... immers can be explained from these two principles: (1) want and omdat categorize the causal relations in the two distinguished domains and (2) when we take argumentative texts to (re)present argumentative discussions the author has a rich choice out of many relevant causalities which he uses strategically.

The last example is more complex but follows from these same two principles. A doctor writes about the phenomenon complaint diagnosis; the patient's complaint is translated by the doctor into another language. In the example Swahili was 
translated into English; in our culture often Latin is used. Actually such a translation does not add any insight, but still it may give the patient the idea that now his situation is clear to the doctor and a treatment will be available. The author says:

Example 6

Zo'n naam kan voor de patiënt een opluchting betekenen omdat nu immers begonnen kan worden met een hoopgevende behandeling.

[Such a name can mean a relief for the patient] omdat immers [now a hopeful treatment can be started].

The rhetorical effect of omdat here is very subtle, and very sympathetic. Notice that the first segment comes from the author/doctor. But the second obviously not! The doctor knows better. It must come from the mouth of the (misleaded) patient and must be reconstructed as: That now a hopeful treatment can be started 'causes' that I (rightly) can feel relieved. While the causality of the doctor is: That the patient (wrongly) concludes that now a hopeful treatment can be started 'causes' that such a name can mean a relieffor the patient. Omdat is part of the 'patient's causality'. If want had been used, the figure would have been similar to example 3; the causality is in the personal epistemic domain of the patient. There is no suggestion of a transfer to the author's epistemic domain. And rightly so, because the other, the doctor's causality explicitly states that the patient is indeed wrong. So the author/ doctor takes a distance. However, by using omdat, the causal relation is presented as a socio-physical relation, the situation is presented as factual. Now a transfer to the personal epistemic domain of the author/doctor is suggested (although blocked again at the same moment by the alternative formulation of the first segment). As a result, the construction as a whole symbolizes sympathy with the mental world of the patient; his inference is presented as logical or at least as understandable, though wrong.

\section{Discussion}

This article explores argumentative texts in which the author of the text does not take up the role of protagonist himself. How does the author make a choice out of many possibilities to present the discourse voice of the protagonist? The use of omdat claims that a causal relation is an element of the shared social-physical domain. The use of want presents the causal relation as an element of the epistemic domain of the relevant discourse voice.

Putting omdat in the mouth of the protagonist makes him present a strong underlying causal relation in the shared social-physical domain-a claimed 'truth'. This gives an author the opportunity to show that he accepts this relation without explicitely stating this (example 1), to ridicule this relation (example 2), or to show a sympathetic understanding of the clamed relation (example 6).

Putting want in the mouth of the protagonist makes him present a causal relation in the individual epistemic domain-a subjective point of view. This gives an author the opportunity to prevent an automatic transfer of the causality via the 
socio-physical domain towards the author's personal epistemic domain (example 3) or to emphasize the subjective commitment of an embedded voice (examples 4 and 5).

The reader/analyst of such polyphonic texts encounters a complex situation. The analyst has to interpret the behavior of the author who presents the (claimed) behavior of the protagonist: analyst-author-discussants. This raises the theoretical issue how to model this intermediate position of the author 'between' the reader/analyst and the protagonist. Are the reader/analysts and the author of the text in fact in a similar position towards the protagonist, namely the position of the actor who reconstructs the discussion? Is the distinction between the analysts and the author only that the knowledge of the analysts is mediated by what the author is willing to reveal? Or is there a more fundamental difference between the positions of the reader/analyst on the one hand and the author of the polyphonic text on the other hand?

Evidently an analyst who makes a rational reconstruction has a commitment. To make a rational reconstruction requires an extensive interpretation of the discussion. This makes the analyst in some sense a participant in the discussion. The reconstruction is an intrinsic part of his evaluation. It would be too weak to state that the analyst only claims: "If my reconstruction is right, then this evaluation is valid". Although an analyst must be granted that position in some situations, usually the analyst claims that his reconstruction is a valid interpretation, not just a possible one.

This however does not imply that the analyst holds a standpoint in the discussion. Here there seems to be a crucial difference between the reader/analyst and the author of these polyphonic fragments. In a considerable number of the fragments the participation of the author in the discussion is more than just that of a reconstructing analyst. He seems to support or challenge the standpoint that is defended by the protagonist, although he assigns the discussant roles of protagonist and antagonist in most cases to other discourse voices. This creates an interesting dilemma.

One option is to ignore the author, to neglect that the author holds or doubts the standpoint. The discussion is reconstructed by the reader/analyst. The author as an intermediate is only relevant as far as the validity of the reconstruction is relative to his integrity. The reader/analyst can state that the validity of his reconstruction is relative to the completeness, the correctness of what is presented by the author of the text, and that is it. The corpus examples illustrate that this solution seems to miss an important aspect of the text, namely that intuitively the author does take part in the argumentative discussion.

A second option is therefore that the reader/analyst indeed reconstructs the author of the text as a protagonist or as an antagonist. In that case the standard pragmadialectical approach is clear and applicable. When a discussant presents the position of his opponent in a specific way to influence the outcome of the discussion in his favor, these choices can be analyzed as a form of strategic manoeuvring (Van Eemeren and Houtlosser 2000): the author optimizes his position, observing the dialectical rules. If this strategic maneuvering derails, if a discussant in doing so violates a discussion rule, the discussant commits a fallacy, according to the concept of fallacies in the pragma-dialectic theory. The fallacy of the straw man is a good candidate when the author seems to present the position of his opponent in an incorrect way. 
In the examples 2 and 3 this is an adequate solution. Here it seems reasonable to ascribe the author the role of antagonist. The reader/analyst has to decide whether he believes that the author is honest and credible in his presentation of his opponent; then no fallacy is committed, just adequate strategic maneuvering is at hand. When the analyst thinks that the author misrepresents the protagonist's position, he reconstructs the discussion in such a way that he evaluates the author/antagonist's behavior as fallacious. The author/antagonist commits the fallacy of the straw man.

In example 1 however this solution is problematic. Here the author seems to adopt the standpoint of the protagonist. But he clearly does not fulfill that role; the quoted expert does. Suppose that the author presents the position of the protagonist as stronger than it actually is brought forward by the expert. Or suppose that the author leaves out relevant speech acts of an antagonist. Then it seems plausible to reconstruct this as committing a fallacy. But how? The only option seems to be to reconstruct the author himself as a protagonist. But then the reference to the embedded voice has to be reconstructed as some form of the argumentum from authority. This all feels as a rather strained construction.

The other examples are even more problematic. In example 4 the author supports the standpoint, but there is a specific protagonist in the text, the public prosecutor. The behavior to be evaluated is the suggestion that Veerman, the antagonist, accepts the argumentation of the protagonist and gives up his doubt on this point. To create this suggestion-by using want-may be judged as committing the fallacy of the straw man. But evidently then this fallacy is not committed then by the public prosecutor, but by the author, which forces us to articulate the roles between these 'two protagonists'.

In example 5 the author may agree with the standpoint of the French president that it is easier to sign a roaring declaration, but disagrees with the standpoint that it is acceptable to sign a roaring declaration. So here the reader/analyst may be forced to reconstruct two discussions with (slightly) different standpoints.

Example 6 is even more complicated. The author is clearly antagonistic towards the patient's standpoint. But he seems to indicate that he is not willing to fulfill that role. To put it in a pragma-dialectical framework; what he seems to indicate is that in the context of the patient, with the shared common grounds that are relevant in that discussion, the standpoint is valid, though it is not valid in a context of the doctor, with the shared common grounds that function there. So again the reader/ analyst has to reconstruct two discussions, but now with the same standpoint, but with different common grounds and therefore with different outcomes. Besides this it seems plausible that in this last example the author honestly attempts to phrase the patient's position, even though he seems to make a very deliberate choice out of all the possible causal relations with the eye on a specific communicative effect. In none of both reconstructed discussions a fallacy seems to be committed.

Both solutions shine light on aspects of the texts. That suggests that we should try to escape the dilemma and develop a third way to reconstruct the argumentation in these complex situations. The criteria that a reconstruction should meet are articulated; it has to balance the responsibilities of the author of the text with on the one hand the responsibilities of the discussants (regulated by the standard pragmadialectic approach) and on the other hand the responsibilities of the reader/analyst 
(accountability for a valid reconstruction of the discussion). The details of such a reconstruction however require further analysis and research.

\section{Conclusion}

Polyphonic texts in which the author of the texts does not fulfill a discussant role but nevertheless seems to have a clear position towards the standpoint are rather frequent. This raises the question how to analyze evaluate the behavior of such an author. Three options can be suggested: to ignore the author, to reconstruct the author still as a protagonist or an antagonist, or to develop a reconstruction that recognizes the specific position of the author. The last option seems to be preferable. To develop such a reconstruction the interactions between the reader/analyst, the author and the discussants need further analysis. If the reader/analyst gives full credibility to the author's presentation of the discussants the author can be ignored. If the reader/analyst can fully identify the author with one of the discussion roles, this can be done. But situations in between these extremes require a range of solutions.

Open Access This article is distributed under the terms of the Creative Commons Attribution Noncommercial License which permits any noncommercial use, distribution, and reproduction in any medium, provided the original author(s) and source are credited.

\section{References}

Houtlosser, P. 1995. Standpunten in een kritische discussie. Dissertation UvA. IFOTT Studies in language use 22.

Pit, M. 2006. Determining subjectivity in text: The case of backward causal connectives in Dutch. In: Discourse Processes 41: 151-174.

Spooren, W., and J. Jaspers. 1990. Tekstoperaties en tekstperspectieven. Gramma/TTT 14: 195-220.

Stukker, N. 2005. Causal marking across levels of language structure. A cognitive semantic analysis of causal verbs and causal connectives in Dutch. Diss. Universiteit Utrecht. Utrecht: LOT.

Sweetser, E.E. 1990. From etymology to pragmatics. Metaphorical and cultural aspects of semantics structure. Cambridge: Cambridge University Press.

Talmy, L. 1988. Force dynamics in language and cognition. In: Cognitive Science 12: 49-100.

van den Hoven, P.J. 2006. Causale connectieven in argumentatietheoretisch perspectief. Taalbeheersing 28(4): 302-323.

van Eemeren, F.H., and R. Grootendorst. 1984. Speech acts in argumentative discussions. A theoretical model for the analysis of discussions directed towards solving conflicts of opinion. Dordrecht/ Cinnaminson: Foris Publications.

van Eemeren, F.H., and P. Houtlosser. 2000. Rhetorical analysis within a pragma-dialectical framework. Argumentation 14(3): 293-305.

Verhagen, A. 2005. Constructions of Intersubjectivity. Discourse, Syntax, and Cognition. Oxford: Oxford University Press. 